\title{
The Ethics of Political Participation: Engagement and Democracy in the 21st Century
}

\author{
Phil Parvin ${ }^{1} \cdot$ Ben Saunders ${ }^{2}$
}

Published online: 9 January 2018

(C) The Author(s) 2017. This article is an open access publication

Keywords Democracy · Participation · Engagement · Civil society · Voting

Democracy today faces many challenges: increasing political inequality, the decline of widespread political participation, voter incompetence, the increasing power of non-majoritarian organisations and institutions on the domestic and global stages, the rise of global problems requiring multilateral collective action, the growing need for specialised expertise in an increasingly complex public policy environment, and the existence of often radical forms of social, political, and moral pluralism all combine to exert significant pressure on existing democratic regimes. They also problematise many of our core assumptions about democracy and its justification. According to one familiar story, the theoretical strength of democracy over other regimes is grounded in strong commitments to political equality and individual liberty, best realised and protected by democratic systems. Individuals enjoy an equal ability to influence the political agenda, either directly or via representatives, and to have their concerns feed into wider processes of decision making and policy formation. Functioning democracies provide meaningful opportunities for citizens to communicate their concerns to decision makers and thereby effectively track the will of the people. Democratic government is self-government: citizens are free in so far as they live as equals under institutions and laws which are accountable to them and which they could change or reject if they so wished.

Phil Parvin

p.parvin@lboro.ac.uk

Ben Saunders

B.M.Saunders@soton.ac.uk

1 Department of Politics, History, and International Relations, Loughborough University,

Loughborough, Leicestershire LE11 3TU, UK

2 Politics and International Relations, University of Southampton, Southampton SO17 1BJ, UK 
But this story is a fiction, at least when compared to democracy as currently practised around the world. Of course, there have long been concerns among political philosophers about the disconnect between the lived reality of democracy and its philosophical justification. For example, in reality power is not exercised by individual citizens but by interest groups, or lobbyists who often work against the public interest rather than for it. But we are arguably reaching a point at which the lived reality of democratic politics is so out of kilter with the philosophical vision on which it is based that the practice is undermining the theory. A growing number of philosophers and political scientists have explained recent failures of democracy in terms of wider, deeper problems with the whole idea. The recent rise of populism, and events such as Britain's withdrawal from the EU ('Brexit') and the election of President Trump, have shaken many people's faith in democracy. The more we learn about these events, the more it seems that the problem is systemic and fundamental (Brennan 2016). Lack of political knowledge, declines in political participation and engagement, distrust of politicians, growing political and economic inequalities, complex and exclusionary systems of voting and registration, and rising political elitism have arguably combined to pull democratic theory and democratic practice in different directions.

What do we do about this? Do we need a new theory of democracy? Or do we need reforms capable of realising the conventional ideal? Political philosophers disagree. Those who believe that we need a new theory do not agree on what this should look like. Achen and Bartels (2016) have argued for a new theory of democracy which takes seriously real-world constraints on, for example, citizen engagement and knowledge. Ilya Somin (2016) and Jason Brennan (2016) have argued for a fundamental reappraisal of democracy in the light of political ignorance among citizens. Hélène Landemore (2017) has suggested that representative democracy is in crisis and needs to be replaced with a system that affords power to citizens directly. Various reform remedies have been proposed. For instance, among deliberative democrats, some have sought to establish mass deliberation among the whole citizen body (e.g. Habermas 1997; Young 2002; Dryzek 2012), while others have advocated limited opportunities for deliberation, perhaps constrained to minipublics, citizens juries, or other deliberative fora (e.g. Fishkin 1991; Fung 2015; Lafont 2014). Others have eschewed the deliberative route, for other approaches more focused on ideas of radical contestation (Laclau and Mouffe 1985; Bevir 2010), or representation (Runciman 2014).

An important theme running through this debate is that participation in democratic life is a good thing and that widespread participation makes democracy stronger. But rates of political participation among citizens of many liberal democratic states are low and, in some countries, declining (Parvin 2009). Many citizens do not want to engage in political activity and are uninterested in politics. This raises profound questions for democratic theory and practice. For example, a number of theorists have suggested that citizens have a duty to participate in democratic life and that, if they fail to discharge this duty, they can be legitimately coerced into participating (Lawrence and Birch 2015; Hill 2015; Lacroix 2007; Lijphart 1997). Others have suggested that political participation is less important than is often thought and should not be coerced (Saunders 2012; 
Lever 2010), or that many citizens are ill-equipped to participate responsibly (Brennan 2012). Others still have argued that we need to expand the opportunities open to individuals to contribute to the democratic system, especially as political participation is declining disproportionately among citizens of a low socioeconomic status. More generally, the changing patterns of political participation observed by political scientists over the past half-century challenge many of the normative approaches to democratic reform popular among political philosophers, as they seem to require wider and richer forms of political participation at a time when citizens do not seem willing or able to engage in even the most minimal forms of participation required by representative democracy (Parvin 2015, 2016).

The essays in this special edition of Res Publica shine new light on some of these challenges, and draw out their implications for democratic theory and practice. They ask a range of connected questions about the ethics of political participation in democracies, including the duties of citizens, appropriate state institutions, and the role of non-state organisations. The questions these authors ask, and the answers they give, strike at the heart of our contemporary democratic predicament, raising profound questions about how our politics should be structured and what it is for.

Sarah Birch seeks to connect normative debates around participation with empirical findings. She argues that it is inappropriate to analyse the decision to vote in economic or rational choice terms, for most people regard voting as a duty. The reason that many people nonetheless fail to vote is that they face a collective action problem and compulsory voting can overcome this by ensuring that each citizen does his or her bit to sustain democracy. The aim is not to reduce the costs of voting, but to ensure that they are equitably shared between all citizens. While Birch notes that equitable burden sharing does not necessarily require every citizen to vote in every election, but might be satisfied by each person voting in alternate elections, she goes on to challenge the view that it is better if some, less knowledgeable, citizens do not vote. Whereas voluntary voting may lead to politics dominated by committed partisans and ideologues, universal participation is likely to lead to more moderate politics. She concludes by arguing that all citizens have an obligation to contribute to the collective good of a democratic polity and that this can justify restricting individual freedom, much as we restrict freedom in other areas of life, such as traffic regulations.

Phil Parvin argues that often democrats place too high a value on citizen participation and engagement in their theories, which renders them problematic when most liberal states are experiencing declining rates of engagement. In particular, he critiques deliberative democratic theory for presupposing and requiring the presence of a flourishing civil society which can build citizens' democratic capacity and mobilise citizens. Parvin draws on empirical data to show that the past five decades or so have seen a withering of the conditions necessary for deliberative democracy to function, which undermines the persuasiveness of deliberative democracy as a strategy for democratic reform. Parvin suggests that deliberative democrats require citizens to participate more often, and in more demanding ways, than they currently do. He argues that instead of requiring more of citizens, we should be requiring less of them, acknowledging that citizens will probably not participate in the volume, or in the ways, that many democratic 
theorists would like. Therefore, we need an alternative approach: a regime which can produce democratic outcomes, and meet the requirements of political equality, without widespread participation among citizens.

Jason Brennan further develops the argument for epistocracy that he presented in his book Against Democracy, by tackling what he calls the 'demographic objection' to his view (Brennan 2016). This objection states that his argument for epistocracy would unfairly concentrate political power in the hands of a privileged, educated elite and would undermine the interests of disadvantaged groups who have not been able to develop their political knowledge to the extent that wealthier people have. Brennan argues that the demographic objection to epistocracy fails and that, to the extent that it undermines epistocracy, it also undermines democracy. If epistocrats should be worried about the demographic objection, then democrats should be worried too, so the demographic objection cannot be used by democrats to reject epistocracy.

Demetris Tillyris discusses the question of political disengagement and its causes. In particular, he asks whether citizens are right to be sceptical about democracy and its ability to achieve what we often think it should. Many citizens disengage from politics because they believe that the system is corrupt or immoral, or that politicians act in ways which are incompatible with democratic values or morality. However, citizens often have unrealistically high expectations of what democracies can achieve, and how 'pure' or 'good' or politics can be. Tillyris argues that politicians should have 'integrity', but that this does not mean they should be necessarily 'virtuous' or morally pure. It may be, therefore, that what citizens see as immoral or unvirtuous behaviour on the part of politicians is nothing of the sort.

Kevin Elliott shifts attention from participation to attentive citizenship. While attentiveness need not lead to active participation-for it is compatible with 'reflective apathy'-it seems necessary for responsible participation. Moreover, attentive citizenship may itself suffice to secure many of the benefits of monitory democracy, even if citizens do not actually participate, for the mere threat of their doing so may motivate elites to anticipate how citizens might respond to their actions. Elliott argues that the democratic state ought to promote attentive citizenship in order to safeguard the fair value of political liberties and to protect groups from under-representation. While some may take these considerations to ground an individual duty to be an attentive citizen, Elliott's concern is with the role of the state. He argues that the state may use coercive means to promote justice and this may justify compelling citizens to vote or to attend civic education courses.

Ben Saunders argues against compulsion, even if universal participation would be beneficial, if it violates a right not to vote. The claim is not simply that compulsion reduces freedom, but that it violates individual rights which constrain what can be done for the good of society. The first part of his paper analyses what such a right might mean, using the framework developed by Wesley Hohfeld (1913). In order to pose an objection to compulsory voting, it would have to be a claim not to be forced to vote, rather than simply a privilege to abstain. The second part of his paper seeks to defend such a right. Saunders does not seek to establish definitively that we have a right not to vote, since this may require a complete 
theory of rights, but he sets out to show that previous criticisms of this right are either unconvincing or miss their target. Some arguments, such as those of Hill (2015), suggest that there is a duty to vote, but this would be compatible with it being rights-violating to force people to do so.

Finally, Eva Erman discusses the legitimacy of civil society actors in global governance. Erman points to the central role that civil society actors of one kind or another play in the development of policy on the world stage and asks whether such actors have a rightful place in a system which understands power as legitimated by the people. She argues that unelected organisations do have a legitimate place in global governance, and so have democratic legitimacy, as long as they fulfil certain 'functions' in this process. Civil society actors' legitimacy has too often been grounded in the role they play in bridging citizens and states, Erman argues. She suggests that we drop this approach and instead look at what more specific functions such actors play, and what specific contributions they make, to democratic decision making on the world stage.

Many of these papers were first presented at a workshop on The Ethics of Political Participation, held at Loughborough University, 21 June 2016. The organiser of that workshop, Phil Parvin, would like to thank everyone who participated in this event, including those in the audience who contributed through their excellent comments and feedback.

Open Access This article is distributed under the terms of the Creative Commons Attribution 4.0 International License (http://creativecommons.org/licenses/by/4.0/), which permits unrestricted use, distribution, and reproduction in any medium, provided you give appropriate credit to the original author(s) and the source, provide a link to the Creative Commons license, and indicate if changes were made.

\section{References}

Achen, Christopher H., and Larry M. Bartels. 2016. Democracy for Realists: Why Elections do not Produce Responsive Government. Princeton, NJ: Princeton University Press.

Bevir, Mark. 2010. Democratic Governance. Princeton, NJ: Princeton University Press.

Brennan, Jason. 2012. The Ethics of Voting. Princeton, NJ: Princeton University Press.

Brennan, Jason. 2016. Against Democracy. Princeton, NJ: Princeton University Press.

Dryzek, John. 2012. Foundations and Frontiers of Deliberative Governance. Oxford: Oxford University Press.

Fishkin, James. 1991. Democracy and Deliberation: New Directions for Democratic Reform. New Haven, CT: Yale University Press.

Fung, Archon. 2015. Putting the Public Back into Governance: The Challenges of Citizen Participation and its Future. Public Administration Review 25: 1-10.

Habermas, Jurgen. 1997. Between Facts and Norms: Contributions to a Discourse Theory of Law and Democracy, William Rehg (trans). Cambridge, MA: MIT Press.

Hohfeld, Wesley.N. 1913. Some Fundamental Legal Conceptions as Applied in Judicial Reasoning. The Yale Law Journal 23: 16-59.

Hill, Lisa. 2015. Does Compulsory Voting Violate a Right Not to Vote? Australian Journal of Political Science 50: 61-72.

Laclau, Ernesto, and Chantal Mouffe. 1985. Hegemony and Socialist Strategy: Towards a Radical Democratic Politics. London: Verso.

Lacroix, Justine. 2007. A Liberal Defence of Compulsory Voting. Politics 27 (3): 190-195.

Landemore, Hélène. 2017. Deliberative Democracy as Open: Not (Just) Representative Democracy. Daedalus 146 (3): 51-63. 
Lawrence, Matthew, and Sarah Birch. 2015. The Democracy Commission: Reforming Democracy to Combat Political Inequality. London: IPPR.

Lafont, Christina. 2014. Deliberation, Participation, and Democratic Legitimacy: Should Deliberative Mini-Publics Shape Public Policy? Journal of Political Philosophy 23 (1): 40-63.

Lever, Annabelle. 2010. Compulsory Voting: A Critical Perspective. British Journal of Political Science 40 (4): 897-915.

Lijphart, Arend. 1997. Unequal Participation: Democracy's Unresolved Dilemma. American Political Science Review 91 (1): 1-14.

Parvin, Phil. 2009. Against Localism: Does Decentralising Power to Communities Fail Minorities? The Political Quarterly 80 (3): 351-360.

Parvin, Phil. 2015. Is Deliberative Democracy Feasible? Trust and Disengagement in Liberal Democratic States. The Monist 98 (4): 407-423.

Parvin, Phil. 2016. Silencing the Critics: Charities, Lobbyists, and the Government's Quiet War on Dissent. Renewal 24 (3): 62-75.

Runciman, David. 2014. The Confidence Trap: A History of Democracy in Crisis from World War 1 to Present. Princeton, NJ: Princeton University Press.

Saunders, Ben. 2012. The Democratic Turnout 'Problem'. Political Studies 60 (2): 306-320.

Somin, Ilya. 2016. Democracy and Political Ignorance: Why Smaller Government is Smarter. Redwood City, CA: Stanford University Press.

Young, Iris.M. 2002. Inclusion \& Democracy. Oxford: Oxford University Press. 